\title{
ОСОБЛИВОСТІ КРИМІНАЛЬНОЇ ВІДПОВІДАЛЬНОСТІ МЕДИЧНИХ ПРАЦІВНИКІВ
}

Давидов П. Г., Юрченко К. Д.

У науковій статті досліджено основні аспекти кримінальної відповідальності лікарів, проведено аналіз окремих норм Особливої частини Кримінального кодексу України, що передбачають медичних працівників як спеціальних суб' $\epsilon$ тів кримінальних правопорушень. Особлива увага приділена аналізу суб'єктивної сторони зазначених злочинів, також акцентовано превентивну функцію зазначених статей Кримінального кодексу України.

Ключові слова: кримінальне правопорушення, склад злочину, кваліфікуючі ознаки, медичні працівники, правова кваліфікація.

В научной статье исследованы основные аспекты уголовной ответственности врачей, проведен анализ отдельных норм Особенной части Уголовного кодекса Украины, предусматривающих медицинских работников в качестве специальных субъектов уголовных правонарушений. Особое внимание уделено анализу субъективной стороны указанных преступлений, а также поставлен акцент на превентивной функции указанных статей Уголовного кодекса Украины.

Ключевые слова: уголовное преступление, состав преступления, квалифицирующие признаки, медицинские работники, правовая квалификация.

Davydov P. H., Yurchenko K. D. Peculiarities of the criminal liability of medical officers

The scientific article examines the main aspects of criminal liability of doctors, analyzes some provisions of the Special Part of the Criminal Code of Ukraine, which provide for medical workers as special subjects of criminal offenses. Particular attention is paid to the analysis of the subjective side of these crimes, and emphasis is placed on the preventive function of these articles of the Criminal Code of Ukraine.

An author marks that the importance of detailed legal regulation of crimes committed by doctors in the course of their professional activities is directly proportional to the state's desire to exercise the rights to public health. The preventive function of the norms of criminal law is an integral stimulus to the conscientious work of a doctor, and the function of legal responsibility ensures both the satisfaction of the injured party and the preservation of the general authority of the health care system. Given the increase in the number of lawsuits filed by citizens regarding the improper provision of medical care, the problems of legal liability of physicians for professional offenses need to be paid much more attention. Therefore, the study of the legal responsibility of medical workers for their offenses and crimes is relevant today. The basis for bringing a medical worker to criminal responsibility is his actions or inaction, which by its nature falls under the crime provided by a special part of the Criminal Code of Ukraine.

At present, the issue of special crimes in the medical field is controversial, because it is for their commission that a medical worker is prosecuted as a special subject of the crime.

Although criminal liability of medical workers has been fully enshrined in the Criminal Code of Ukraine. According to the anal-

( С Давидов П. Г., Юрченко К. Д., 2020 ysis norms, a medical worker acts as a special subject of a crime. The professional medical crimes themselves are detailed and fully disclosed within the framework of criminal law. In the legal qualification of this type of crime, special attention should be paid to the subjective side, as it is important to determine the intent of the medical worker to commit crimes. The presence of a category of "good reasons" for not providing medical care also makes it difficult to fully define the subjective side.

Key words: criminal offense, corpus delicti, qualifying features, medical workers, legal qualification.

Постановка проблеми та їі актуальність. Важливість детальної правової реґламентації злочинів, учинюваних лікарями під час професійної діяльності, прямо пропорційна прагненню держави щодо реалізації прав на охорону здоров'я громадян. Превентивна функція норм кримінального законодавства $€$ невід'ємним стимулом до сумлінної роботи лікаря, а функція юридичної відповідальності забезпечує як сатисфакцію потерпілої сторони, так і збереження загального авторитету системи охорони здоров'я. Останнє пояснюється можливістю довіри до спеціаліста лише за умови відповідальності з його боку. Саме із цих причин варто звернути увагу на окремі норми Особливої частини Кримінального кодексу Україні, що прямо стосуються медичних працівників як суб'єктів злочинів.

Метою статті $\epsilon$ виокремлення основних особливостей кримінальної відповідальності медичних працівників за скоєння злочинів під час виконання професійних обов'язків на основні аналізу окремих норм Особливої частини Кримінального кодексу України, що передбачають медичного працівника як особливого суб'єкта злочину.

Актуальність досліджуваної теми полягає у важливості якісної правової реґламентації кримінальної відповідальності медичних працівників як для захисту їніх прав, так і інших сторін відповідних правовідносин, спричинених скоєнням кримінального правопорушення в медичній сфері.

Предметом дослідження виступають Кримінальний кодекс України й інші нормативно-правовові акти, які регулють аспекти кримінальної відповідальності медичних працівників.

Завдання роботи:

1. Дослідження умов суспільної реальності в контексті криміналної відповідальності медичних працвників.

2. Аналіз основних фунцій механізму кримінальної відповідальності медичних працівників.

3. Аналіз окремих норм особливої частини Кримінального кодексу України, що передбачають медичного працвника як спеціального суб'єкта злочину.

Аналіз останніх досліджень і публікацій. Окремі питання юридичної відповідальності медичних працівників, зокрема і кримінальної, досліджувались у робо- 
тах Ю.В. Бауліна, В.І. Борисова, С.Б. Гавриша, М.В. Радченко, А.А. Тарасової, а також у працях С.Г. Стеценко, В.В. Сташиса, І.Я. Сенюти.

Методологічну основу дослідження становить теорія пізнання, її загальний метод матеріалістичної діалектики. Як загальнонаукові методи дослідження застосовувалися такі: формально-логічний і системний методи наукового пізнання, опис, порівняння, аналіз і синтез.

Виклад основного матеріалу. Суспільна реальність вимагає створення дієвої системи гарантій надання професійної медичної допомоги. 3 метою дотримання прав громадян важливо забезпечити безперебійне функціонування зазначеного механізму шляхом створення узгодженої правової основи. Зрозуміло, що правова основа не може виключати норми впливу на потенційних та діючих правопорушників. Вплив може здійснюватись як шляхом заохочення медичних працівників (майнового і немайнового характеру), так і встановлення жорсткої відповідальності за правопорушення, учинені у зв'язку з виконанням ними своїх повноважень. Розгалужена система заохочень закріплена трудовим законодавством України й іншими нормативно-правовими актами, які не $\epsilon$ предметом розгляду даної роботи. Натомість особливу увагу варто звернути на особливості відповідальності медичних працівників за вчинення правопорушень, оскільки ціна за незнання законів може бути занадто високою для окремого індивіда. Знання про підстави, види і наслідки юридичної відповідальності, з одного боку, дисциплінує медичних працівників, а з іншого - зменшує ймовірність безпідставного притягнення їх до відповідальності.

Беручи до уваги збільшення кількості позовних заяв громадян щодо неналежного надання медичної допомоги, проблемам юридичної відповідальності медиків за професійні правопорушення треба приділяти значно більше уваги. Тому дослідження юридичної відповідальності медичних працівника за вчинення ними правопорушень та злочинів $\epsilon$ актуальним.

Поширена думка, що юридична відповіадьність має в основі застосування примусу з боку уповноважених органів за вчинення дій, що кваліфікуються нормативно-правовими актами як правопорушення, злочини чи проступки [5]. Згідно зі ст. 80 Закону України «Основи законодавства про охорону здоров'я», особи, винні в порушенні вимог медичного законодавства, несуть цивільну, адміністративну або кримінальну відповідальність згідно із законодавством України. У даному разі можна говорити про наявність практично всіх видів юридичної відповідальності, які обираються залежно від суб'єкта, завданої шкоди, виду правовідносин тощо. Розвиток цих видів відповідальності передусім зумовлений ухваленням Цивільного кодексу України, поступовим розвитком законодавства з охорони здоров'я та напрацюванням судової практики в розгляді справ про притягнення медичних працівників до відповідальності [4]. Найжорсткішим видом відповідальності медичних працівників $\epsilon$ кримінальна відповідальність. Кримінальна відповідальність - окремий вид юридичної відповідальності, що проявлється в обов'язку особи, яка вчинила суспільно небезпечне діяння, що підпадає під ознаки злочину, передбаченого окремою статею Особливої частини Кримінального кодексу України, зазнати обмежень прав у формі кримінального покарання. Підставою для притягнення медичного праців- ника до кримінальної відповідальності є його дії чи бездіяльність, що за своїми ознаками підпадає під склад злочину, передбаченого Особливою частиною Кримінального кодексу (далі - КК) України [5; 6].

Натепер спірним $\epsilon$ питання спеціальних злочинів у медичній сфері, адже саме за їх учинення медичний працівник притягається до кримінальної відповідальності як особливий суб'єкт злочину. Дефініцію цього злочну висловив С.Г. Стеценко, який зазначив, що під професійним злочином варто розуміти умисне або необережне діяння, учинене медичним працівником під час виконання професійних обов'язків, заборонене кримінальним законом під загрозою покарання [6]. Вичерпний перелік таких злочинів міститься у Кримінальному кодексі України. 3 метою аналізу правової реґламентації кримінальної відповідальності медичних працівників за вчинення ними професійних злочинів варто проаналізувати окремо кожен склад злочину, який підпадає під ознаки професійного злочину в медичній сфері.

Найжорсткішим злочином у контексті досліджуваної теми можна назвати злочин, передбачений ст. 119 КК України. Зазначена стаття встановлює загальну норму стосовно кримінальної відповідальності за неумисне завдання смерті іншій людині. 3 об'єктивної сторони цей злочин характеризується діянням, яким заподіюється смерть іншій людині, наслідком у вигляді смерті та причиновим зв'язком між наслідком та зазначеним діянням. Заподіяння смерті через необережність $€$ ознакою майже сімдесяти злочинів, у разі підпадання діяння за більшістю ознак до одного із зазначених злочинів, кваліфікація не буде проходити за ст. 119 КК. Наприклад, у ст. 141 передбачено необережність у суб'єктивній частині, підлягає окремій кваліфікації. Натепре неумисне завдання медичним працівником смерті іншій людині кваліфікується за ст. 119 КК України «Вбивство через необережність». Відповідальність за таке діяння обмеження або позбавлення волі на строк від трьох до п'яти років. Убиство же двох або більше осіб, скоєне через необережність, карається позбавленням волі на строк від п'яти до восьми років [2]. Загальний характер зазначеного вимагає особливої уваги під час застосування щодо медичних працівників, адже здебільшого можна застосовувати статті Особливої частини КК із більш деталізованою диспозицією.

Наступним кримнальним правопорушенням, на яке варто звернути увагу, $\epsilon$ неналежне виконання професійних обов'язків, що спричинило зараження особи вірусом імунодефіциту людини чи іншої невиліковної інфекційної хвороби. У цьому разі вже наявне діяння у вигляді неналежного виконання професійних обов'язким медичним, фармацевтичним працівником унаслідок несумлінного ставлення до них. Тобто склад зазначеного злочину вже безпосередньо стосується медичних працівників. За дії такого характеру кримінальне законодавство встановлює відповідальність у вигляді обмеження або позбавлення волі на строк до трьох років. Якщо ж такі дії призвели до зараження такими хворобами двох чи більше осіб, то закон передбачає санкцю у вигляді позбавлення чи обмеження волі на строк від трьох до восьми років [5]. До особи, яка вчинила такий злочин, застосовується додаткове покарання - позбавлення права обіймати посади, пов'язані з медичною чи фармацевтичною діяльністю на строк до трьох років. Поняття неналежного виконнання професійних обов'яз- 
ків, що є частиної об'єктивної сторони, можна сформулювати як недбале, поверхове виконання професійних обов'язків, усупереч інтересам професійної діяльності.

Кримінальне законодавство поширюється і на кримінальні правопорушення, об'єктом яких виступає порядок обігу інформації про проведення медичного огляду на виявлення зараження вірусом імунодефіциту людини чи іншої невиликовної інфекційної хвороби. За ст. 132 КК України розголошення службовою особою лікувального закладу, допоміжним працівником, який самочинно здобув інформацію, або медичним працівником відомостей про проведення медичного огляду особи на виявлення зараження вірусом імунодефіциту людини чи іншої невиліковної інфекційної хвороби, що $\epsilon$ небезпечною для життя людини, або захворювання на синдром набутого імунодефіциту (далі - СНІД) та його результатів, що стали їм відомі у зв'язку з виконанням службових або професійних обов'язків, призводить до кримінальної відповідальності [1]. Санкція такого суспільно небезпечного діяння - альтернативна, а отже, на розгляд суду до суб'єкта, який учинив цей злочин, може бути обрано один із таких видів покарань, як:

- штраф від п'ятдесяти до ста неоподатковуваних мінімумів доходів громадян;

- громадські роботи на строк до двохсот сорока годин; - виправні роботами на строк до двох років;

- обмеження волі на строк до трьох років [1].

Зазначеному злочину також притаманний спеціальний суб'єкт у вигляді службової особи лікувального закладу, допоміжного працівника такого закладу чи медичного працівника. Об'єктивна строна полягає в розголошенні відомостей щодо медичного огляду пацієнта або його результатів. Розголошення відомостей означає, що особа, яка зобов'язана зберігати інформацію, незаконно ознайомлює з нею сторонніх осіб чи створює умови для такого ознайомлення.

Також до осіб, які вчинили цей злочин, може застосовуватись додаткове покарання - позбавлення права обіймати певні посади чи займатися певною діяльністю на строк до трьох років.

На окрему увагу заслуговує і ст. 134 КК України «Незаконне проведення аборту або стерилізації». 3 огляду на те, що постанова Кабінету Міністрів України № 144 від 15 лютого 2006 р. встановила, що в разі хвороби вагітної жінки за її заявою Міністерством охорони здоров'я Автономної Республіки Крим, Управлінням охорони здоров'я обласної та Севастопольської міської державних адміністрацій і Головним управлінням охорони здоров'я Київської міської державної адміністрації створюється комісія [5; 7]. Така комісія ухвалює рішення щодо штучного переривання вагітності [6]. Якщо ухвалено позитивне рішення про переривання вагітності, воно здійснюється в акредитованих закладах охорони здоров'я особою, яка має необхідну спеціальну медичну освіту. У такому разі аборт визначено законним.

Особливу увагу варто приділяти ч. ч. 1 та 3 ст. $134 \mathrm{KK}$ України, оскільки склади злочинів, зазначені в цих частинах, передбачають спеціального суб'єкта. По-перше, проведення аборту особою, яка не має спеціальної медичної освіти, карається штрафом від п'ятдесяти до ста неоподаткованих мінімумів доходів громадян або громадськими роботами від ста до двохсот сорока годин, виправними роботами від двох років, обмеженням волі на строк до двох років [1]. Суб'єктом злочину в такому разі можуть виступати лікарі, що здобули вищу медичну освіту, однак не мають спеціальної медичної підготовки, за характером своєї професійної діяльності неуповноважені на проведення операцій зі штучного переривання вагітності, середній медичний персонал чи особи, що взагалі не мають стосунку до медичної діяльності. По-друге, незаконне проведення аборту, якщо воно спричинило тривалий розлад здоров'я, безплідність або смерть потерпілої, карається обмеженням волі на строк до п'яти років або позбавленням волі на той самий строк із позбавленням права обіймати певні посади чи займатися певною діяльністю на строк до трьох років або без такого [2]. Зазначений склад злочину $€$ матеріальним, передбачає настання конкретних наслідків. Оскільки аборт передбачає пряме втручання з метою переривання вагітності, то випадки з викиднем унаслідок неналежної медичної допомоги мають кваліфікуватися за ч. 2 ст. 140 КК України.

Окремого вивчення заслуговує ст. 139 КК України, що передбачає відповідальність за неданання без поважних причин медичної допомоги хворому медичним працівником, який відповідно до встановлених правил зобов'язаний надавати медичну допомогу. У кваліфікації зазаначеного кримінального правопоршення важливу роль відіграє визначення категорії «поважні причини», адже її наявність радикально змінює суб'єктивну сторону правопорушення. Найбільш точне визначення цієї категорії запропоноване В.В. Сташисом і Ю.В .Бауліним [5, с. 287]. Ці вчені зазначають, що поважними причинами, які не дали можливості надати допомогу, можуть визнаватися: дія нездоланної сили, поломка автомобіля, на якому медичний працівник доїжджав до хворого, знесений повністю міст через річку, дія інших стихійних сил природи. Поважною причиною може також визнаватися хвороба самого медичного працівника, відсутність у нього медикаментів чи інструментів або практичного досвіду тощо. Питання про визначення причини поважною вирішує суд. У такому разі медичний працівник не може посилатись на такі обставини, як неробочий час, відпочинок, відпустка тощо [4].

За ненадання без поважних причин допомоги хворому медичним працівником законом передбачено покарання у вигляді штрафу до п'ятдесяти неоподатковуваних мінімумів доходів громадян із позбавленням права обіймати певні посади чи займатися певною діяльністю на строк до трьох років або виправними роботами на строк до двох років. У ч. 2 зазначеної статті передбачено тяжкі наслідки, спричинені ненаданням медичної допомоги. Саме тому за скоєння таких дій передбачено покарання у вигляді обмеження волі на строк до чотирьох років або позбавлення волі на строк до трьох років, з позбавленням права обіймати певні посади чи займатися певною діяльністю на строк до трьох років або без такого [1].

Одним із найважливіших етапів даного дослідження $\epsilon$ аналіз злочину, передбаченого ст. 140 КК. Відповідно до цієї статті, невиконання чи неналежне виконання медичним або фармацевтичним працівником своїх професійних обов'язків унаслідок недбалого чи несумлінного до них ставлення, якщо це спричинило тяжкі наслідки для хворого, карається позбавленням права обіймати певні посади чи займатися певною діяльністю на строк до п'яти років або виправними роботами на строк до двох років, або обмеженням волі на строк до 
двох років, або позбавленням волі на той самий строк [3]. Значне поширення цього злочину зумовлює необхідність детального аналізу як його складу, так і особливостей кваліфікації.

Об'єктивна сторона злочину полягає в:

- діянні (невиконання медичним або фармацевтичним працівником своїх професійних обов'язків унаслідок недбалого чи несумлінного до них ставлення):

- тяжких наслідках для хворого;

- причиновому зв'язку між вказаним діянням та наслідками.

У ч. 2 ст. 140 встановлено кримінальну відповідальність за неналежне виконання чи невиконання медичним або фармацевтичним працівником своїх професійних обов'язків унаслідок недбалого чи несумлінного до них ставлення, якщо це спричинило тяжкі наслідки неповнолітньому. Зазначені діяння караються обмеженням волі на строк до п'яти років або позбавленням волі на строк до трьох років, з позбавленням права обіймати певні посади чи займатися певною діяльністю на строк до трьох років [5, с. 289].

Потерпілим від злочину $є$ хворий у значенні «паці$\epsilon$ Тт», оскільки термін «Хворий» виражає нездужання людиною від певної хвороби, а термін «пацієнт» визначає особу, що звернулася по медичну допомогу, або особу, яка нікуди не зверталася, але медична допомога їй надається (перебування особи в непритомному стані).

Злочин уважається скоєним із моменту настання тяжких наслідків для потерпілого. Під тяжкими наслідками можна розуміти смерть, самогубство, тяжкі тілесні ушкодження тощо. Суб'єкт злочину - спеціальний (медичні та фармацевтичні працівники). Суб'єктивна сторона зазначеного злочину характеризується злочинною самовпевненістю - необережність, якщо особа передбачала можливість настання суспільно небезпечних наслідків свого діяння (дії або бездіяльності), але легковажно розраховувала на їх відвернення, та злочинною недбалістю через необережність, якщо особа не передбачала можливості настання суспільно небезпечних наслідків свого діяння (дії або бездіяльності), хоча повинна була і могла їх передбачити [1].

Під правовою охороною перебуває порядок залучення людей до проведення клінічних випробувань лікарських засобів. Такий порядок реґламентований у Законі України «Про основи законодавства про охорону здоров'я» та наказі Міністерства охорони здоров'я № 690 від 23 вересня 2009 р. «Про порядок проведення клінічних випробувань лікарських засобів та експертизи матеріалів клінічних випробувань» [4]. Відповідно до ст. 141 КК України, порушення прав пацієнта, пов'язане із проведенням клінічних випробувань лікарських засобів без письмової згоди пацієнта або його законного представника, або стосовно неповнолітнього чи недієздатного, якщо ці дії спричинили смерть пацієнта або інші тяжкі наслідки, карається обмеженням або позбавленням волі на строк від трьох до п'яти років [5, с. 289].

Окрему увагу законодавцем було приділено незаконному проведенню дослідів над людиною. Особлива важливіть дослідження зазначеного злочину полягає в антигуманному та непрофесійному характері дій суб'єкта злочину, що прямо суперечить професійній етиці лікаря та найбільше дискредитує лікарську діяльність. За ст. 142 КК України такі діяння призводять до кримінальної відповідальності, якщо це створювало небезпеку для життя чи здоров'я людини. Санкція названої статті альтернативна та передбачає штраф до двохсот неоподатковуваних мінімумів доходів громадян або виправні роботи на строк до двох років, або обмеження волі на строк до чотирьох років, з позбавленням права обіймати певні посади чи займатися певною діяльністю на строк до трьох років [3]. У ч. 2 ст. 142 передбачено, що незаконне проведення дослідів, скоєне щодо неповнолітнього, двох або більше осіб, шляхом примушування або обману, а також якщо вони спричинили тривалий розлад здоров'я потерпілого, караються обмеженням волі на строк до п'яти років або позбавленням волі на той самий строк, з позбавленням права обіймати певні посади чи займатися певною діяльністю на строк до трьох років або без такого [7]. Основним терміном, від якого потрібно відштовхуватися під час кваліфікації зазначеного злочину, $є$ «дослід»- експеримент, спроба відтворити щось нове, таке, чого раніше не існувало, з метою його випробовування.

Еволюційного розвитку в національному законодавстві набуває правове регулювання порядку трансплантації органів або тканин людини. У ст. 143 КК України визначено, що порушення встановленого законом порядку трансплантації органів або тканин людини карається штрафом до п'ятдесяти неоподатковуваних мінімумів доходів громадян або виправними роботами на строк до двох років, або обмеженням волі на строк до трьох років, з позбавленням права обіймати певні посади чи займатися певною діяльністю на строк до трьох років або без такого [1]. У ст. 143 під трансплантацією розуміється спецілальний метод лікування, що полягає в пересадці рецепієнту органа чи іншого анатомічного матеріалу, взятих у людини. Більш жорстке покарання передбачено за вчинення дій, що виражаються у формі вилучення в людини шляхом примушування або обману іï органів або тканин з метою їх трансплантації. Караються такі діяння обмеженням або позбавленням волі на строк до трьох років із позбавленням права обіймати певні посади чи займатися певною діяльністю на строк до трьох років [1]. Якщо ж дії, передбачені ч. 2 цієї статті, учинені щодо особи, яка перебувала в безпорадному стані або в матеріальній чи іншій залежності від винного, то вони караються обмеженням волі на строк до п'яти років або позбавленням волі на той самий строк, з позбавленням права обіймати певні посади чи займатися певною діяльністю на строк до трьох років або без такого. У ч. 4 ст. 143 КК України встановлено кримінальну відповідальність за незаконну торгівлю органами або тканинами людини. Вказані дії караються обмеженням або позбавленням волі на строк до п'яти років. Водночас ч. 5 ст. 143 КК України встановлює такі обтяжуючі обставини цього злочину:

потерпіла особа перебувала в безпорадному стані або в матеріальній чи іншій залежності від винного;

- злочин учинений за попередньою змовою групою осіб;

винна особа брала участь у транснаціональних організаціях, які займаються незаконною торгівлею органами або тканинами людини [5 с. 290].

Суб'єкт зазначеного злочину загальний, але здебільшого їм виступає медичний працівник, який має можливості та ресурси для скоєння зазначеного кримінального правопорушення. Суб'єктивна сторона характеризується прямим умислом. Наявна спеціальна мета - 
вилучення в людини органів або тканин для подальшої трансплантації.

Висновки. У результаті проведеного дослідження можна сказати, що кримінальна відповідальність медичних працівників повноцінно закріплена у Кримінальному кодексі України. Медичний працівник, згідно із проаналізовними нормами, виступає спеціальним суб'єктом злочину. Самі ж професійні медичні злочини деталізовані та повною мірою розкриті в рамках кримінального законодавства. Суб'єкт зазначених злочинів спеціальний і окремо визначений кримінальним законодавством. Під час правової кваліфікації зазначеного типу злочинів особливу увагу варто приділяти суб'єктивній стороні, оскільки велике значення має визначення умислу медичного працівника на вчинення злочинів. Наявність категорії «поважних причин» у разі ненадання медичної допомоги також ускладнює повне визначення суб'єктивної сторони. Встановлення ж об'єкта й об'єктивної сторони не виділяється особливою складністю.

\section{Література}

1. Кримінальний кодекс України. URL: https:// zakon.rada.gov.ua/laws/show/2341-14.

2. Кримінальний кодекс України : науково-практичний коментар / Ю.В. Баулін та ін. ; за заг. ред.
В.В. Сташиса, В.Я. Тація. Київ : Концерн «Видавничий дім «Ін Юре»», 2003. 1196 с.

3. Науково-практичний коментар Кримінального кодексу України. 7-ме вид., переробл. та доп. Кив : Юридична думка, 2010. 1288 с.

4. Основи законодавства України про охорону здоpoв'я. URL: https://zakon.rada.gov.ua/laws/show/2801-12.

5. Галкін І.С. Кримінальна відповідальність медичних працівників за вчинення професійних злочинів. Актуальні проблеми політики. 2015. Вип. 55. C. 283-291.

6. Стеценко С.Г., Стеценко В.Ю., Сенюта І.Я. Медичне право України : підручник. Всеукраїнська асоціація видавців «Правова єдність», 2008. 507 с.

7. Сучасне українське медичне право : колективна монографія / авт. кол. : Н.Б. Болотіна та ін. ; за заг. ред. С.Г. Стеценка. Київ : Атіка, 2010. 495 с.

Давидов П. Г., кандидат філософських наук, доцент кафедри мовних та гуманітарних дисциплін № 1 Донецького національного медичного університету

Юрченко К. Д., студентка IV курсу медичного факультету № 1 Донецького національного медичного університету 